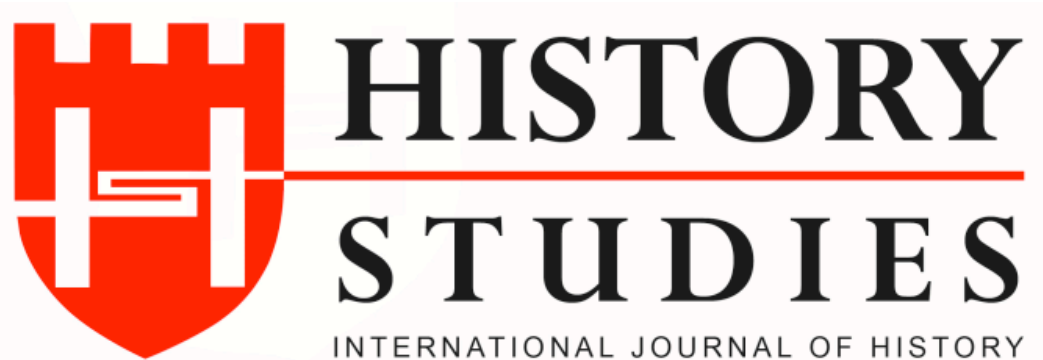

ISSN: 13094173 (Online) 1309 - 4688 (Print)

Volume 12 Issue 1, February 2020

DOI Number: 10.9737/hist.2020.822

Araştırma Makalesi

Makalenin Geliş Tarihi: 19.09.2019 Kabul Tarihi: 25.12.2019

Atıf Künyesi: Abdullah Cengiz, “Kudüs-i Şerif İdadi Mektebi (1890-1913)”, History Studies, 12/1, Şubat 2020, s. 103-124.

\title{
Kudüs-i Şerif İdadi Mektebi (1890-1913)
}

\author{
Jerusalem High School (1890-1913)
}

\author{
Arş. Gör. Abdullah Cengiz \\ ORCID No: 0000-0002-3484-2308 \\ Dicle Üniversitesi
}

\section{$\ddot{0} z$}

Osmanlı Devleti, kuruluşundan Tanzimat Dönemi’ne kadar olan süreçte eğitim sistemini geleneksel bir modelle icra etmiştir. Geleneksel modelin en önemli kurumları ise medrese ve sıbyan mektepleriydi.

II. Mahmut döneminden itibaren geleneksel modelle birlikte modern eğitim yöntemi uygulanmaya başlanmış ve II. Abdülhamit döneminde ise modern eğitim yöntemi ivme kazanmıştır. Modern eğitim yönteminin kurumları iptidai, rüştiye, idadi, sultani ve meslek okullarıdır. Bu okullar ilk olarak İstanbul'da daha sonra diğer vilayet ve sancaklarda açılmıştır.

Çalışmada, Osmanlı Devleti'nin sahip olduğu geleneksel ve modern eğitim sistemi hakkında kısaca bahsedilmiştir. Osmanlı arşivi belgeleri ve maarif yıllıkları (salnameler) esas alınarak Kudüs-i Şerif sancağında kurulan idadi mektebinin açılışı, idari-öğretim kadrosu, müfredatı ve öğrenci sayıları hakkında detaylı bilgi verilmiştir. Elde edilen verilere göre, mektebi nitelikli hale getiren unsurun muallimlerin donanımları olduğu görülmüştür. $\mathrm{Bu}$ sebeple nitelikli muallimler ödüllendirilmiştir. Diğer bir husus mektep idaresi, değişen koşulları ve çevre dinamiklerini göz önünde bulundurarak hareket etmiştir. Böylelikle Kudüs-i Şerif sancağında açılan idadi mektebi, bölge çocuklarının hem ihtiyaçlarına cevap vermiş hem de kendi memleketlerinde okuyabilme imkânını sağlamıştır.

Anahtar Kelimeler: Osmanlı Devleti, Kudüs, Eğitim Sistemi, İdadi Mektebi, Öğretim Kadrosu

\section{Abstract}

The Ottoman Empire carried out the education system with a traditional model from the foundation until the Tanzimat Period. The most important institutions of the traditional model were madrasah and primary schools.

Starting from the II. Mahmut era, modern education method has been applied together with the traditional model and during the reign of II. Abdülhamit, the modern education method gained momentum. The institutions of modern education method are iptidai, rüştiye, idadi, sultani and vocational schools. These schools were first opened in Istanbul and then in other provinces and sanjak

In this study, the traditional and modern education system of the Ottoman Empire is briefly mentioned. Detailed information was given about the opening of the administrative school established in the Sanjak of Jerusalem, based on the Ottoman archive documents and the Ottoman education year

\section{History Studies}


(salnames), administrative-teaching staff, curriculum and the number of students. According to the data obtained, it was seen that the teachers who provided the principal arbitrariness to the school were the equipment. For this reason, arbitrary teachers were awarded. Another point was the school, taking into consideration changing conditions and environmental dynamics. Another point was the school, taking into consideration changing conditions and environmental dynamics.

Keywords: Ottoman Empire, Jerusalem, Education System, High ( İdadi) School, Teaching Staff

\section{Giriş}

İdadi, "hazırlamaya mahsus yer, hazırlama yeri" anlamına gelmektedir. ${ }^{1}$ İdadi kavramı, Osmanlı'da Tanzimat Dönemi'nin ilk yıllarına kadar Batı tarzında açılan okulların hazırlık sınıfları ve 1847 yılında açılmış olan rüştiyelere öğrenci hazırlamaya ayrılan sıbyan mektepleri için kullanılmıştır. ${ }^{2}$ Yine Osmanlı Devleti'nin Harp Okulu'nda ve Askeri Tıbbiye'de öğrenim görmek isteyen ancak eğitim düzeyi bu okulların eğitimine başlayabilecek düzeyde olmayan öğrencileri askeri okulların programlarını takip edebilecek duruma getirmek amacıyla açılmış

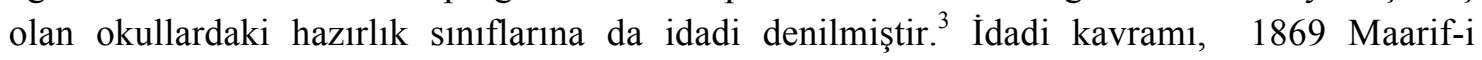
Umumiye Nizamnamesi'nde orta öğretimin bir kademesi olarak ele alınmış ve böylece eskiden ifade ettiği anlamı kaybederek yeni bir mana/muhteva kazanmıştır. ${ }^{4}$

Tanzimat döneminden sonra devlet kurumlarında nitelikli memurların eksikliği eğitim sistemini sorgular hale getirmiştir. Eğitim sistemini nitelikli hale getirmek ve daha geniş bir alana yaymak için yasal düzenlemeler yapılmıştır. Öte yandan vilayetlerde rüştiye üstünde ve İstanbul'da yüksekokullara talebe yetiştirecek -rüştiye dışında- bir okul olmadığından idadi mekteplerin açılması elzem hale gelmiştir. Böylelikle 1869 Maarif-i Umumiye Nizamnamesi ile idadi mekteplerin yasal statüsü yeniden düzenlenerek Osmanlı eğitim sisteminde yerini almıştır. Nizamname ile açılması kararlaştırılan idadiler 1874 tarihine kadar ne taşrada, ne de İstanbul'da açılabilmiştir. İdadilerin hayata geçiril(e)memesi eğitim ve öğretim alanındaki ilerlemeyi engellemiştir. ${ }^{5}$

İdadilerin bir an önce faaliyete geçip eğitim vermesi için 07 Ocak 1874 tarihli irade ile İstanbul'da numune olarak bir idadinin açılması kararlaştırılmıştır. Bununla birlikte aynı yıl, Yanya Vilayeti Tırhala sancağının merkezi olan Yenişehir'de bulunan rüştiye mektebi, idadiye çevrilmiştir. Böylece ortaöğretimin birinci kademesini oluşturması kararlaştırılan idadilerin ilk örnekleri, 1874 yılında, hem İstanbul'da hem de taşrada açılmıştır. Nizamname ile teşkil edilmek istenen ortaöğretim kurumlarının gerek İstanbul'da gerekse taşrada yapılandırılması ve yaygınlaştırılması ancak Sultan II. Abdülhamid döneminde hayata geçirilebilmiştir. ${ }^{6}$

\footnotetext{
${ }^{1}$ Ferit Devellioğlu, Osmanlıca-Türkçe Ansiklopedik Lûgat, Aydın Kitabevi Yay. Ankara, Baskı:30, İ Maddesi. 2013, s.471

${ }^{2}$ Cemil Öztürk, "İdâdî”, DİA, C.21, İstanbul, 2000, s.464

${ }^{3}$ Faik Reşit Unat, Türk Eğitim Sisteminin Gelişmesine Tarihi Bir Bakış, Milli Eğitim Bakanlığı Yayınevi, Ankara, 1964, s.45

${ }_{5}^{4}$ Bayram Kodaman, Abdülhamid Devri Ĕgitim Sistemi, Türk Tarih Kurumu Yay. Ankara, 1999, s.114

5 Fatih Demirel, "Osmanlı Eğitim Sisteminin Modernleşmesi Sürecinde Hiyerarşi”, Uludağ Üniversitesi Ĕğitim Fakültesi Dergisi, 25 (2), 2012, s.518

${ }^{6}$ Demirel, a.g.m. s.518-519; Fatih Demirel, "Kuruluşundan Günümüze Vefa Lisesi”, Prof. Dr. Yahya Akyüz'e Armağan Türk Eğitim Tarihi Araştırmaları, Eğitim ve Kültür Yazıları, Pegem Akademi Yayınları, Ankara 2010, s.608
} 
Osmanlı'da idadilerin önemi anlaşılmasına rağmen, maddi yetersizlikten dolayı hemen idadiler açılamamıştır. ${ }^{7}$ İdadilerin gerek daimi giderleri, gerekse tesis ve inşa masrafları için çok miktarda paraya ihtiyaç vardı. Sadrazam Said Paşa'nın gayretleriyle bir takım maddi kaynaklar sağlanarak idadi mekteplerin yapımına başlanmıştır. Buna göre, 1885 yılından itibaren Bursa, Edirne, Yanya, Çanakkale'de birer idadi mektebi açılırken; İzmir, Selanik, Trabzon, Rodos, Konya, Mamuratülaziz, Ankara, Üsküp, Priştine, Serfice, Gümülcine, Manisa, Adana, Halep, Maraş, Kırşehir, Çankırı, Teke, Bitlis, Muş, Kastamonu, İzmit, Sivas ve Kudüs-i Şerif'te idadi mektebi açılmasına karar verilmiş ve yapımlarına başlanmıştır. Ayrıca, Erzurum, Hakkâri, Diyarbekir, Zor, Burdur, Karesi, Kaza-i Erbaa, Karahisar-1 Sahip, Kırklareli gibi yerlerde de birer idadi yapılması için mahalli makamlarla temasa geçilmiştir. ${ }^{8}$

İdadiler, ilk yıllar 1869 Nizamnamesi'ne ve 1874'te açılan mülki idadi için öngörülen bazı hükümlere göre idare edilmişlerdir. 1892 yılında idadiler için bir talimatname hazırlanarak müdürlerin, muavinlerin, mubassırların vazifeleri ve talebelerle ilgili hususlar ayrıntılı bir şekilde hükümlere bağlanmıştır. Bu hükümler vesilesiyle idadilere olan rağbet artmış ve eskiye göre idadilerin talebe sayısında önemli bir artış olduğu tespit edilmiştir. Bu talebin karşılanması için Osmanlı Devleti'nde idadi mekteplerin açılmasına hız verilmiştir. 1896 yılında 54 olan taşra idadilerinin sayısı 1906 yılında 84'e çıkmıştır. Böylece bütün Osmanlı Devleti topraklarında 93 resmi; 11 hususi; 5'de askeri olmak üzere toplam 109 tane idadi mektebi açılmıştır. ${ }^{9}$

\section{Kudüs-i Şerif'in Kısa Tarihçesi}

Kudüs yaklaşık 4000 y1llık geçmişe sahip eski bir şehirdir. Kudüs, tarih boyunca farklı kültürlerin ilgisini çekmiş ve bu sebeple de çeşitli devletlerin hâkimiyetinde kalmıştır. ${ }^{10}$ Hristiyanların elinde bulunan Kudüs, Hz. Ömer zamanında Müslümanların yönetimine geçmiştir. Hz. Ömer'den sonra Kudüs'e, Emeviler, Abbasiler, Tolunoğulları, Fatimiler hâkim olmuştur. 1099 yılında şehir haçlıların işgaline uğrayarak Fatimilerin elinden çıkmıştır. Haçlıların hâkimiyetinde 88 yıl kalan Kudüs'ü Selahaddini Eyyübi 1187 yılında geri almıştır. ${ }^{11}$

Kudüs, Suriye'deki Eyyubiler ile Memlükler arasında birkaç defa el değiştirmiştir. Abbasi Halifesi Müsta‘sım-Billah'ın aracılı̆̆ıyla Suriye'deki Eyyubiler ve Memlükler arasında yapılan barış antlaşması ile Kudüs Memlükler'e bırakılmıştır. Ancak Kudüs 1256 yılında tekrar Eyyubilerin eline geçmiştir. Memlüklülerin Moğollar'a karşı kazanılan Aynicalut zaferiyle Eyyubi hanedanı da sona ermiş ve böylece Kudüs 1517 yılına kadar Memlüklülerin hâkimiyetinde kalmıştır. ${ }^{12}$

1517 yılında Osmanlı padişahı Yavuz Sultan Selim, Mısır seferinde Kudüs'ü fethetmiştir. Kudüs'ün fethinden sonra Yavuz Sultan Selim, şehrin ismini Kudüs-i Şerif koymuştur.

\footnotetext{
${ }^{7}$ Hatip Yıldız, "Üsküdar (Paşakapısı) Mülki İdadi Mektebi (1893-1923)", Uluslararası Üsküdar Sempozyumu VIII, 21-23 Kasım 2014 C.I, İstanbul 2015, s.419

${ }^{8}$ Kodaman, a.g.e. , s. 117

${ }^{9}$ Kodaman, a.g.e., s.126-129.

${ }^{10}$ Cengiz Batuk, Rabia Mert, "Çatışan Kutsalların Ortasındaki Şehir: Kudüs", Din Bilimleri Akademik Araştırma Dergisi, Cilt 17, Say1 2, 2017, s.134.

${ }^{11}$ Casim Avc1, Fethedilişinden Haçlı İstilâsına Kadar: Kudüs”, DİA, C. 26, Ankara 2002, s.327-329

${ }^{12}$ Cengiz Tomar, Memlükler Dönemi: Kudüs”, DİA, C. 26, Ankara 2002, s.332-333
} 
Osmanlı, Kudüs-i Şerif'e önemli hizmetler götürmüştür. Özellikle Kanuni Sultan Süleyman döneminde büyük imar faaliyetleri gerçekleştirilmiştir. IV. Murad, Abdülmecid, Abdülaziz ve II. Abdülhamid, Kudüs-i Şerif için pek çok hizmette bulunmuştur. Kudüs-i Şerif, Osmanlı yönetimi altında hep sancak statüsünde kalmakla birlikte bağlı bulunduğu merkez zamanla değişmiştir. 1517-1831 yılları arasında Şam Eyaleti, 1841-1865 yılları arasında Sayda Eyaleti ve bu son tarihte Sayda ve Şam Eyaletlerinin birleştirilmesiyle oluşturulan Suriye Vilayeti içinde yer almıştır. 1872-1917 döneminde ise müstakil mutasarrıflık statüsü verilerek doğrudan merkezi hükümete bağlanmıştır. 1517 yılında başlayan Kudüs-i Şerif’teki Osmanlı yönetimi 1917 yılına kadar devam etmiştir. 1917 yılında Kudüs-i Şerif İngiliz manda yönetimi altına girmiştir. ${ }^{13}$

\section{Kudüs-i Şerif İdadi Mektebi’nin Yapım ve Açılışı}

Osmanlı Devleti'nin diğer taşra topraklarında olduğu gibi Kudüs-1 Şerif sancağında da idadi mektebinin açılması kararlaştırılmış ve idadi mektebi için en iyi yerin Memnuniye Medresesi olduğu tespit edilmiştir. Memnuniye Medresesinin arazisine idadi mektebinin yapılması için mektepte kullanılacak taşların cinsi ve fiyatını, mimar ve amele yevmiyelerine harcanacak olan paranın miktarını gösteren keşif defteri Maarif Nezareti'ne gönderilmiştir. Bir yandan idadi mektebinin yapılacağı yerin aşırı ölçüde tahrip olduğu tespit edilmiş, diğer yandan ise Maarif Nezareti'nden gelecek cevabın 6 ay sürmesi nedeniyle mektebin yapımında kullanılacak olan taşın fiyatı, mimar ve amelelerin yevmiyeleri hızla arttığı görülmüştür. Bu yüzden yeniden keşif defteri hazırlanılarak 28 Şevval 1302 (10 Ağustos 1885) tarihinde Maarif Nezareti'ne gönderilmiştir. Maarif Nezareti ise bu keşif defterini incelemiş ve mektebin yapımı-tamiri için 330,000 kuruşun tahsis edilmesini uygun görmüştür. ${ }^{14}$

Maarif Nezareti'nden çıkan izin neticesinde 1885 yılında Memnuniye Medresesi'nin arazisine idadi mektebi yapılmaya başlanmış ve bitimi üç yıl sürmüştür. Ancak Memnuniye Medresesi'nin arazisi küçük olduğundan Kudüs-i Şerif Rum Patriği Niko Demyos Efendi, Rum Patrikhanesi'ne ait arsayı idadi mektebine hibe etmiştir. ${ }^{15}$ Buna rağmen idadi mektebi için hibe edilen arsa yetersiz gelmiştir. Bu sebeple Kudüs-i Şerif Maarif Müdürlüğü, idadi mektebinin bitişiğinde bulunan basmahane ve çömlekhanenin kendisine hibe edilmesini istemiş ve aynı zamanda üç hususu da keşif defterine ekleyerek Maarif Nezareti'ne bildirmiştir. Bu hususlardan birincisi; mektebe duvar çekilmesi, ikincisi; basmahane ve çömlekhane yer seviyesinin mektebin zemini ile aynı seviyeye getirilmesi, üçüncüsü ise; mektebin ileride yatılı olma ihtimali göz önünde bulundurularak mektebe mutfak ve kömür mahzeni inşa edilmesi için toplam masraf olarak 234,812 kuruşun Kudüs-i Şerif Maarif gelirlerinden karşılanmasını istemiştir. ${ }^{16}$ Ancak bu talebe/isteğe, 1888 yılının Eylül ayına kadar cevap gelmemiştir. Bunun üzerine Maarif Nezareti'ne tekrardan yazı gönderilmiş ${ }^{17}$ ise de Kudüs-i Şerif İdadi Mektebi'nin tamir ve inşasında 234,812 kuruşun Kudüs-i Şerif Maarif gelirlerinden kullanılmasına dair

\footnotetext{
${ }^{13}$ Kâmil Cemîl el-Aselî, "Osmanlı Dönemi ve Sonrası: Kudüs”, DİA, C. 26, Ankara 2002, s.334-338

${ }^{14}$ BOA (Devlet Arşivleri Başkanlığı Osmanlı Arşivi) Maarif Nezareti Mektubi Kalemi Evrakı, (MF. MKT.), 143/24; BOA, MF. MKT, 101/48

${ }^{15}$ BOA, Dâhiliye Nezareti İrade Dâhiliye Evrakı (İ.DH.) , 1054/82713

${ }^{16}$ BOA, MF. MKT, 101/48

${ }^{17}$ BOA, MF. MKT, 102/43
} 
iznin nezaretçe verildiğine dair bir belgeye rastlanılmamıştır. Ancak Kudüs-i Şerif Maarif Müdürlüğü tarafından Maarif Nezareti'ne gönderilen bir belgede, mektebin tamiratının iki yıl gibi zaman içerisinde tamamlandığı ve talebe kabul edecek hale geldiği bilgisi yer almaktadır. Buradan hareketle 234,812 kuruşun kullanılmasına dair iznin verildiği anlaşılmaktadır.

Kudüs-i Şerif Maarif Müdürlüğü, idadi mektebinin tamiratının bitmesi ve talebe kabul edecek hale gelmesinden sonra mektepte görev alacak kişilerin tayininin müsaade yazısını şu şekliyle "Mescid-i Aksa müderrislerinden ve Kudüs-i Şerif Rüsstiye Mektebi muallimlerinden Ebusuudzade Şeyh Tahir Efendi'nin Arapça derslerine girmesi; Paris mekteplerinde eğitim görmüs ve ecnebi mekteplerinde muallimlik vazifesini birçok müddet ifa etmiş, Osmanlı Devleti vatandaşı olan Mösyö Kalmin'in Franslzca dersine girmesi; bu iki muallimin haricinde mektepte talim ve tedris edilecek olan derslerin muallimleri de İstanbul'dan gönderilmesi" Maarif Nezareti'ne iletmiştir. Nezaret ise bir mektebin eğitim-öğretim yılının ortasında açılmasının uygun olmadığını belirtmiş; ancak eğitim-öğretim yılı başlangıcında muallimlerin mektebe tayininin yapılabileceğini bildirilmiştir. ${ }^{18}$

İdadi mektebinin yapımı kararı 1885 tarihinde alınmış ve 3 yıl içerisinde mektebin yapımı tamamlanmış ise de mektebin açılışı, 15 Zilkade 1307 (3 Temmuz 1890) tarihinde Kudüs-i Şerif mutasarrıfı, askeri erkân, memur ve halkın katılımıyla gerçekleşmiştir. Mektep, beş yıllık ve gündüzlü program kapsamında açılmış ve mektebe müdür ve muallimlerin tayini yapılarak eğitim-öğretim yılına resmi olarak 1890 yılı itibariyle başlamıştır. ${ }^{19}$

\section{Mektebin İdari ve Öğretim Kadrosu}

İdadi mekteplerinde görevli olarak müdür, müdür-i sani, muavinler, muallimler, kâtipler, mubassırlar bulunmaktaydı. Bu görevliler, Maarif Nezareti tarafindan tayin edilmekteydi. Mektebin idaresinde en üst amir olarak müdür yer almaktaydı ve yaptığı işlerden Maarif Müdürlüğü'ne karş1 sorumluydu. Müdür, eğitim-öğretim faaliyetlerinin düzgün bir şekilde devam ettirmek, mektepteki memur ve muallimlerin mekteple ilgili vazifelerini takip etmek, mektebin demirbaş eşyasını ve mekteple ilgili araç-gereçleri muhafaza etmek ile görevliydi. ${ }^{20}$

Müdürün en yakın yardımcısı ve müdürden sonra mektebin idaresinden sorumlu olarak müdür-i sani bulunmaktaydı. Müdürün mektepte bulunmadığ zamanlarda, müdürün yerine vekâleten mektebe bakan müdür-i sani mektebin işlerini yürütürdü. Diğer bir görevli olan mubassırlar öğrencilerin durum ve davranışlarını denetlemekle; kâtipler ise mektebin bütün hesap işlerinden ve yazı işlerinden sorumludur. ${ }^{21}$

Muallimlerin görevleri ise, mektebin eğitim-öğretim işlerini yapmak ve ders işlerken müfredata uymaktı. Muallimler, mektepteki görevleri dışında başka bir işle meşgul olamaz ve hiçbir sebep/bahane ile derslerini terk edemezlerdi. Eğer muallimler, dersleri terk ederlerse maaşlarından ücret kesilirdi. Mektebe gelemeyecek derecede hasta olan muallimin yerine, derse vakıf olan başka bir muallim tayin edilerek eğitime hiçbir suretle ara verilmezdi. Ayrıca eğitimi

\footnotetext{
${ }^{18}$ BOA, MF. MKT, $115 / 68$

${ }^{19}$ BOA, MF. MKT, 120/94

${ }^{20}$ Fatih Demirel, Mekteb-i İdâti, (Atatürk Üniversitesi, Sosyal Bilimler Enstitüsü, Yayınlanmamış Doktora Tezi),

Erzurum 2010, s.61-63

${ }^{21}$ Demirel, a.g.t., s. $65-72$
} 
güzel bir şekilde yapmayan, vazifesini yerine getirmeyen ve derste gürültüye engel olmayan muallimler hakkında yevmiye kesintisi uygulanırdı. ${ }^{22}$

Kudüs-i Şerif İdadi Mektebi beş yıllık ve gündüzlü program olarak açılmış ve ardından mektebe müdür, kâtip, mubassır ve muallimler tayin edilmiştir. Mektebe tayin edilen görevlilerin başında müdür gelmekteydi. Mektebe müdür olarak ilk kimin atandığına dair herhangi bir belgeye rastlanılmamıştır. Ancak mektebin açılışından yaklaşık bir yıl sonra 1891 tarihli belgeye bakıldığında, Tarih-i Tabii dersini, mektep müdürü Hüseyin Efendi'nin verdiği bilgisine rastlanılmaktadır. Bu bilgiden hareketle mektebin ilk müdürünün Hüseyin Efendi olduğu söylenebilir. ${ }^{23}$ Hüseyin Efendi'nin mektepten ne zaman ayrıldığ 1 ise bilinmemektedir. Hüseyin Efendi'den sonra müdürlük görevine Celal Efendi geçmiştir. Celal Efendi belirtilen görevde bir müddet kaldıktan sonra 1893 yılında Diyarbekir İdadi Mektebine tayin olmuştur. ${ }^{24}$ Celal Efendi'nin yerine ise Hüseyin Bedri Efendi geçmiştir.

Hüseyin Bedri Efendi daha önce Halep İdadi Mektebi'nde görev yapmış, 1250 kuruş maaşla Kudüs-i Şerif İdadi Mektebi Müdürlüğü’ne 28 Rebiyülâhır 1312 (29 Ekim 1894) tarihinde tayin olmuş ve müdürlük göreviyle birlikte mektebin Fransızca, Usul-i Defteri, Malumat-1 Fenniye derslerine de girmiştir. Ancak Hüseyin Bedri Efendi göreve başladıktan yaklaşık yedi ay sonra vücudunda hastalıklar zuhur etmiştir. Hüseyin Bedri Efendi, hastanede muayene olmuş ve muayene sonucu "hastanın Kudüs-i Şerif sancağının iklimine imtizacı olmadığı ve daha uygun bir yere tayin edilmesi gerektiği” şeklinde rapor almıştır. Hüseyin Bedri Efendi hastaneden aldığı rapor ile tayin dilekçesini 19 Zilkade 1312 (14 Mayıs 1895) tarihinde Maarif Nezareti'ne iletmiştir.

Maarif Nezareti, Hüseyin Bedri Efendi'nin tayin dilekçesine şu şekilde cevap göndermiştir: Hüseyin Bedri Efendi'nin özel durumu göz önünde bulundurulmuş fakat özel durumuna ilişkin şimdilik boş bir yer bulunmadığı, ancak hastalığı çok şiddetli ise ileride açılacak münasip bir yere tayin edilene kadar istifa edebileceği bildirilmiştir. Maarif Nezareti'nin bu kararına binaen Hüseyin Bedri Efendi, doktor raporu ile bir ay izin alarak İstanbul'a gitmiş ve burada bir ay kaldıktan sonra tekrar iki ay izin almıştır. Bu süre zarfında ise Kudüs-i Şerif İdadi Mektebi müdürsüz kalmıştır. Bu yüzden Hüseyin Bedri Efendi'nin yerine Selanik İdadi Mektebi'nin muavini evveli olan Faik Efendi, Kudüs-i Şerif İdadi Mektebi'ne 8 Safer 1313 (31 Temmuz 1895) tarihinde 1450 kuruş maaşla müdür olarak tayin edilmiştir. Faik Efendi müdürlük göreviyle birlikte mektebin Fransızca, Usul-i Defteri, Malumat-1 Fenniye, İnşa ve Kitabet derslerine de girmiştir. Faik Efendi, müdürlük görevini yaklaşık üç yıl icra ettikten sonra yerine Mehmed Hayri Efendi getirilmiştir. Mehmed Hayri Efendi, Kudüs-i Şerif İdadi Mektebi'nde bir yıl kaldıktan sonra Kastamonu İdadi Mektebi müdürü Abdullah Fevzi Efendi ${ }^{25}$ ile becayişi yapılmıştır. ${ }^{26}$

\footnotetext{
${ }^{22}$ Demirel, a.g.t., s. 78-79

${ }^{23}$ BOA, MF. MKT. 132/89

${ }^{24}$ BOA, MF. MKT. 163/1

${ }^{25}$ Abdullah Fevzi Efendi'nin önceki müdürlügü ve becayişine konu olan durum belgede şu şekilde yer almaktadır: Kastamonu İdadi Mektebi müdürü Abdullah Fevzi Efendi, Kastamonu'ya tayin edilmeden önce Erzurum İdadi Mektebi'nde müdürlük görevini ifa ederken dizanteri hastalığına yakalanmış ve bu hastalık yüzünden müdürlük görevini yerine getiremez hale gelmiştir. Bu sebeple Abdullah Fevzi Efendi Erzurum'dan Kastamonu İdadi
} 
Kudüs-i Şerif İdadi Mektebi Müdürlüğü'ne becayişi yapılan Abdullah Fevzi Efendi'nin belirtilen görevde kaç yıl kaldığı tam olarak bilinmemektedir. Ancak H. 1321 (M.1903) yılı Maarif Salnamesi kaydına göre bu tarihte Kudüs-i Şerif İdadi Mektebi Müdürlüğü görevini Halid Efendi yürütmekteydi. ${ }^{27}$ Halid Efendi, müdürlük görevini yürütürken elli dört talebeye uygunsuz davranışlarda bulunmuş ve muallimlerin görevleriyle ilgili keyfi kararlar almıştır. Halid Efendi hakkındaki şikâyetler, Maarif Nezareti'ne bildirilmiş ancak hakkındaki iddiaların aslı astarı olmadığı anlaşılmıştır. ${ }^{28}$

Manastır İdadi Mektebi Müdürlüğü’ne Harput İdadi Mektebi müdürü Zekeriya Efendi tayin edilince Zekeriya Efendi'nin yerine (Harput İdadi Mektebi Müdürlüğ̈̈’ne) ise Halid Efendi 11 Rebiyülâhır 1324 (4 Haziran 1906) tarihinde tayin edilmiştir. ${ }^{29}$ Bu sebeple boşalan Kudüs-i Şerif İdadi Mektebi Müdürlüğü'ne Kıbrıs İdadi Mektebi müdürü Halil Efendi, 16 Rebiyülâhır 1324 (9 Haziran 1906) tarihinde 1390 kuruş maaşla tayin edilmiştir. Halil Efendi, müdürlük görevinin yanında mektebin üçüncü ve dördüncü sınıf Türkçe, Ahlak, Coğrafya ve Kitabet derslerine de girmiştir. ${ }^{30}$ Halil Efendi'nin göreve başlamasından bir yıl sonra hakkında memnuniyetsizlik oluşmaya başlamıştır. Bu memnuniyetsizliğin sebebi ise Halil Efendi’nin görevini hakkıyla ifa edememesi olarak gösterilmiştir. Öyle ki Halil Efendi'nin mektebi terakki ve ihya ettirmesi gerekirken, aksine Kudüs-i Şerif'te bulunan halkı mektepten uzaklaştırmıştır. Bu yüzden Halil Efendi'nin Ankara Vilayeti dâhilinde Kırşehir sancağı İdadi Mektebi Müdürlüğü'ne tayin edilmesi ve yerine de tecrübeli-bilgili olan Kırşehir İdadi Mektebi Müdürü Nabi Efendi'nin getirilmesi talep edilmiştir. Halil Efendi ile Nabi Efendi'nin becayiş durumu Maarif Nezareti'nce de uygun görülerek Nabi Efendi, Kudüs-i Şerif Maarif Müdürlüğü’ne 6

Volume 12 Issue 1 February 2020 Şaban 1325 (14 Eylül 1907) tarihinde 1210 kuruş maaşla tayin edilmiştir. Nabi Efendi, müdüriyet göreviyle birlikte mektebin Ahlak, Coğrafya, Kitabet, Türkçe derslerine de girmiş $\mathrm{ve}^{31}$ mektepteki görevini bir yıl sürdürdükten sonra Kudüs-i Şerif Kaymakamlı̆̆ı'na terfi etmiştir. Bunun üzerine Beyrut Vilayeti Aka İdadi Mektebi’nin müdürü olan Kamil Efendi, (Beyrut Vilayeti'nin rutubetli havasıyla uyum sağlayamadığından) boş kalan müdürlüğe tayinini istemiş̦ir. Kamil Efendi'nin bu talebi Maarif Nezareti'nce uygun görülerek 1060 kuruş maaşla Rebiyülâhır 1326 (5 Mayıs 1908) tarihinde müdürlüğe tayin edilmiştir. Kamil Efendi, müdüriyet göreviyle birlikte mektebin Coğrafya, Kitabet, Türkçe derslerine de girmiştir. ${ }^{32}$

\footnotetext{
Mektebi'ne tayin edilmiştir. Ancak Kastamonu'nun da havası Erzurum gibi soğuk ve nemli olmasından dolayı Abdullah Fevzi Efendi'nin hastalıkları tekrar zuhur etmiş ve dolayısıyla Abdullah Fevzi Efendi müdürlük görevini yapamaz hale gelmişti. Abdullah Fevzi Efendi, Erzurum ve Kastamonu gibi soğuk memleketler yerine havası sıcak olan yerlere tayinini istemiştir. Bunun üzerine Abdullah Fevzi Efendi’nin Kudüs-i Şerif İdadi Mektebi müdürüyle (Mehmed Hayri Efendi) becayişi uygun görülmüştür. Abdullah Fevzi Efendi, Kudüs-i Şerif İdadi Mektebi Müdürlüğü'ne 20 Receb 1317 (24 Kasım 1899) tarihinde 1290 kuruş maaşla becayişi yapılmıştır. Abdullah Fevzi Efendi müdürlük göreviyle birlikte mektebin Fransızca, Türkçe, Hendese, Usul-i Defteri ve Malumat-1 Fenniye derslerine girmiştir.(BOA, MF. MKT, 479/4).

${ }^{26}$ BOA, MF. MKT, 479/4

${ }^{27}$ Maarif Salnamesi, H. 1321, s.727

${ }^{28}$ BOA, MF. MKT, 898/50

${ }^{29}$ BOA, MF. MKT, 932/59

${ }^{30}$ BOA, MF. MKT, $958 / 73$

${ }^{31}$ BOA, MF. MKT, 1013/3

${ }^{32}$ BOA, MF. MKT, 1005/1
} 
Kudüs-i Şerif İdadi Mektebi 1913 tarihine kadar idadi olarak faaliyetini icra etmiştir. Bu tarihten sonra ise idadi mektebi, sultani mektebine dönüştürülmüştür. Kudüs-i Şerif İdadi Mektebi'nin açılışından sultaniye dönüştürülmesine kadarki zaman zarfında mektebe tayin olunan muallimlerin tamamı tespit edilememiştir. Ancak arşiv kaynakları ve salnamelerden elde edilen bilgiler 1şı̆̆ında Kudüs-i Şerif İdadi Mektebi'ndeki muallimler ve girdikleri/verdikleri dersler aşağıda sistematik bir şekilde tablo ile gösterilmeye çalışılmıştır:

Tablo 1: 1895-1904 Yılları Arasında Kudüs-i Şerif İdadi Mektebi’nde Görev Alan Muallimlerin Çizelgesi

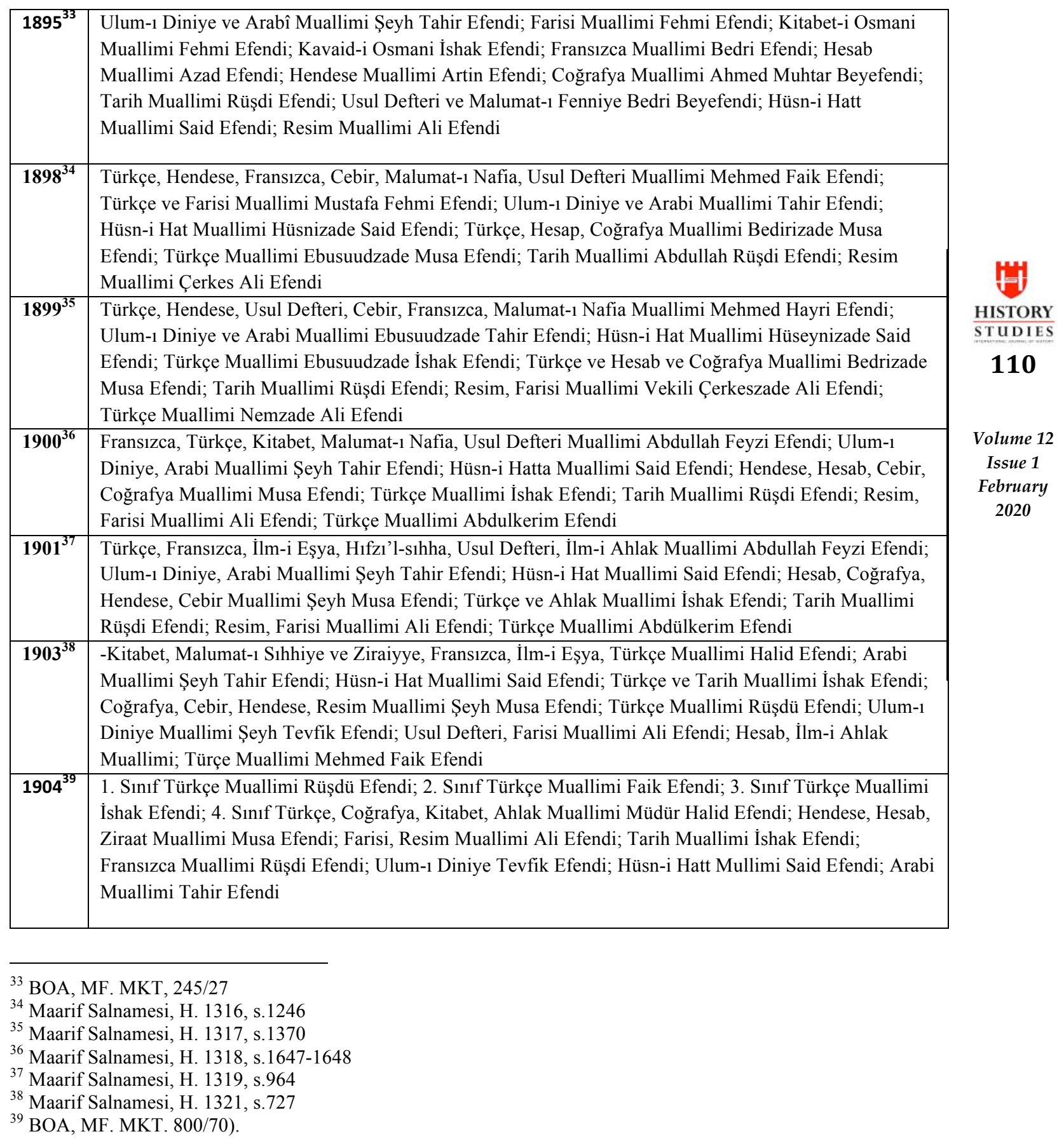


İdadi mektebinde görevini iyi yapan ve talebelerin yetişmesinde gayret gösteren muallimler nişan ile taltif edilirdi. Örneğin Kudüs-i Şerif sancağında Beşinci Ordu-yu Hümayun'da komutan olan ve Kudüs-i Şerif İdadi Mektebi'nde Hesap ve Hendese muallimliği yapan Yüzbaşı Ahmed İzzet Efendi, askerlik vazifesini hakkıyla yapması ve mektebin terakki etmesine katkı sağlaması nedeniyle dördüncü rütbeden Mecidiye Nişanı ile taltif edilmesi Kudüs-i Şerif Mutasarrıflığı'nca istenilmiş ${ }^{40}$ ise de Ahmed İzzet Efendi'nin 500 kuruş maaş karşılığında (idadi mektebinde) görev yaptığı ve rütbesini daha yeni aldığ ${ }_{1}^{41}$ gibi sebeplerden dolayı Kudüs-i Şerif Mutasarrıflı̆̆ı'nın talebi Maarif Nezaretince uygun görülmemiştir. ${ }^{42}$

Muallimlerin mektepteki görevi, mesai saatlerinde mektepte bulunmak ve talebenin mektebe olan devamlılığını sağlamaktır. Belirtilen görevi yerine getirmeyen muallimlere ya uyarı cezası ya da görevlerine son verilirdi. ${ }^{43}$ Mektep Müdürü, mektepte bulunan muallimlerin ve eğitim gören talebelerin devamlarını içeren cetveli (1893 Yılı Haziran-Ağustos) düzenleyerek 1 Cemaziyülevvel 1311 (10 Kasım 1893) tarihinde Maarif Nezareti'ne göndermiştir. Maarif Nezareti'ne intikal eden cetvelde eğitim gören talebelerin çoğunluğunun devamsızlıktan dolayı sınıfı geçemediği görülmüştür. $\mathrm{Bu}$ durum devam ederse mektepten gerekli semere alınamayacağı ve bu durumu engellemek için bir takım tedbirlerin alınması gerektiği yönünde mektep müdürü uyarılmıştır. ${ }^{44}$ Yine mektepte eğitim gören talebe sayısında azalma olduğundan Maarif Nezareti, 8 Cemaziyülahır 1320 (12 Eylül 1902) tarihinde müdürlüğe gönderdiği yazı ile muallimlerinin daha dikkatli olması ve mektepte talebenin sayısının artmasına daha ziyade ehemmiyet göstermesi yönünde tembihatta/uyarıda bulunmuştur. ${ }^{45}$

Belgelerden elde edilen Kudüs-i Şerif İdadi Mektebi’nin talebe sayısı ve bunların yıllara göre dağılımı aşağıda gösterilmiştir.

Tablo 2: 1897-1904 Yılları Arasında Kudüs-i Şerif İdadi Mektebinde Bulunan Talebe Sayısı

\begin{tabular}{|c|c|c|c|c|c|}
\hline \multicolumn{3}{|l|}{$1897-1898^{46}$} & \multicolumn{3}{|l|}{$1901-1902^{47}$} \\
\hline Gayr-i Müslim & Müslim & Toplam & Gayr-i Müslim & Müslim & Toplam \\
\hline 1 & 80 & 81 & --- & 103 & 103 \\
\hline \multicolumn{3}{|l|}{$1898-1899^{48}$} & \multicolumn{3}{|l|}{$1903-1904^{49}$} \\
\hline Gayr-i Müslim & Müslim & Toplam & Gayr-i Müslim & Müslim & Toplam \\
\hline 1 & 88 & 89 & --- & 123 & 123 \\
\hline
\end{tabular}

\footnotetext{
${ }^{40}$ BOA, MF. MKT, 136/45).

41 "Devlete hizmette özel gayret ve başarı göstermiş olan herhangi bir kişiyi ödüllendirmek için Mecidiye Nişanı verilmiştir. Mecidiye Nişanı Nizamnamesi'nin 12. Maddesi’ne göre mecidiye nişanın ilk önce beşinci rütbesi verilecektir. Aynı nizamnamenin 13. maddesi gereğince bu nişanın bir rütbesinden diğerine geçmek için nişan sahibinin devletine üstün başarı ile hizmet etmiş ve en az beşinci rütbede iki yıl, dördüncü, üçüncü ve ikinci rütbelerde üçer yıl beklemiş olmak gerekmektedir." (Kemal Hakan Tekin, "Osmanlı Devletinde Gelenekten Yeniliğe Geçişin Anlamlı Bir Sembolü: Mecidi Nişanları” The Journal of Academic Social Science Studies, Number: 28, Autumn II, 2014, s.401-402)

${ }_{42}$ BOA, MF. MKT, 149/127).

${ }^{43}$ Demirel, agt, s.79

${ }^{44}$ BOA, MF. MKT, 190/112

${ }^{45}$ BOA, MF. MKT, 657/40

${ }^{46}$ Maarif Salnamesi, H. 1316, s. 1247

${ }^{47}$ Maarif Salnamesi, H. 1319:965

${ }^{48}$ Maarif Salnamesi, H. 1317:1471

${ }^{49}$ Maarif Salnamesi, H. 1321:728
} 
Kudüs-i Şerif İdadi Mektebi (1890-1913)

\begin{tabular}{|l|l|l|l|l|l|}
\hline $\mathbf{1 9 0 0 - 1 9 0 1}^{\text {50 }}$ & & & \\
\hline Gayr-i Müslim & Müslim & Toplam & & & \\
\hline 2 & 106 & 108 & & & \\
\hline
\end{tabular}

Kudüs-i Şerif sancağında bulunan iptidai mekteplerdeki talebelerin imtihanı Arapça lisanı ile yapılmaktaydı. Bunun sebebi ise bu mekteplerde bulunan muallimlerin Türkçe'yi bilmemesiydi. İptidai mekteplerde talebelerin imtihanı Türkçe lisanı ile olması gerekirdi. Bu yüzden 1905 yılında bir Darülmuallimin-i İbtidai Mektebi açılması uygun ve zaruri görülmüştür. Ancak bu mektep için Kudüs-i Şerif sancağında uygun bir bina yapmak veya kiralamak durumu olmadığından şimdilik mektebin Kudüs-i Şerif İdadi Mektebi dâhilinde hizmet vermesi uygun görülmüştür. ${ }^{51} \mathrm{Bu}$ mektebin amacı, Kudüs-i Şerif sancağında bulunan iptidai mekteplerdeki muallimlere Türkçe lisan öğretmekti.

Kudüs-i Şerif İdadi Mektebi ile Darülmuallimin-i İbtidai Mektebi aynı binada hizmet vermeye başlamıştır. Binada iki mektep olduğu için bu iki mektebin idaresi de müdürleri tarafından yürütülmüştür. Ancak Kudüs-i Şerif İdadi Mektebi'nin Müdürü, Darülmuallimin-i İbtidai Mektebi'nin idaresine müdahale etmiştir. Darülmuallimin-i İbtidai Mektebi Müdürlüğü müdahaleyi engellemek için durumu Maarif Nezareti'ne bildirmiştir. Maarif Nezareti, durumu hoş karşılamamış ve Kudüs-i Şerif İdadi Mektebi Müdürü'nü Darülmuallimin-i İbtida Mektebi'nin idaresine karışmaması için uyarmıştır. ${ }^{52}$ Belgelerden ortaya çıkan sonuç şudur: Mektebin intizam ve disiplin içerisinde eğitim ve öğretim faaliyetlerini yürütmesi için Maarif Nezareti, yeri geldiğinde mektep idaresi ve muallimlerine uyarılarda bulunmuş ve gerekli tedbirlerin alınmasını onlardan istemiştir.

İdadi mekteplerinde bulunan mubassırlar, talebelerin teneffüsteki davranışlarını denetlemek ve onlara namaz vakitlerinde nezaret etmek ile görevliydiler. ${ }^{53}$ Kudüs-i Şerif İdadi Mektebi’nin açılışı (1890) üzerinden üç yıl geçmesiyle talebe sayısı seksene kadar yükselmişti. 1893 eğitimöğretim yılında idadi mektebi beş sınıf ve seksen talebeden teşekkül etmiştir. Mektep tarafından bu sınıf ve talebelere bir mubassırın refakat etmesi kâfi görülmemiştir. Bu yüzden Kudüs-i Şerif İdadi Mektebi Müdürlüğü nizam ve düzenin sağlanması için mevcut mubassırın yanına bir mubassırın daha tayin edilmesini Maarif Nezareti'nden istemiştir. Maarif Nezareti, idadi mektebine ikinci bir mubassır tayin edilmesini uygun görmemiş ve gerekçe olarak da İdadi Mektepleri Müteşekkil Komisyon Kararını ${ }^{54}$ göstermiştir. $^{55}$

\section{Mektebin Öğretim Programı}

İdadi mektepleri, ilk y1llar 1869 Nizamnamesi'ne ve 1874'te açılan mülki idadi için öngörülen bazı hükümlere göre idare edilmiştir. İdadi mektepleri açılmaya başladıktan sonra, Maarif Nezareti'nde kurulan komisyon tarafından ders programları düzenlenmiştir. Ancak 1869

\footnotetext{
${ }^{50}$ Maarif Salnamesi, H. 1318:1648

${ }^{51}$ BOA, MF. MKT, 812/33

${ }^{52}$ BOA, MF. MKT, 919/20; BOA, MF. MKT, 922/17

${ }^{53}$ Demirel, agt, s. 72

54 İdadi Mektepleri Müteşekkil Komisyonu'nun kararı şu şekildedir: Umum gündüzlü idadi mekteplerinde birer mubassırın istihdam edilmesi uygundur.

${ }^{55}$ BOA, MF. MKT, 173/99
} 
Abdullah Cengiz

Nizamnamesi ile 1874'te açılan mülki idadi için öngörülen bazı hükümlere göre ders programlarında köklü bir değişiklik yapılmamıştır. ${ }^{56}$

Osmanlı Devleti'nin Kudüs-i Şerif sancağında 1890 tarihinde açılan Kudüs-i Şerif İdadi Mektebi'nde (nehari/gündüzlü beş yıllık) okutulan derslerin adı, haftalık saatleri ve muallimlerin aldıkları ücretler aşağıdaki tabloda verilmiştir.

Tablo 3: Kudüs-i Şerif İdadi Mektebi’nde Okutulan Derslerin Adı, Haftalık Saati ve Ücreti ${ }^{57}$

HISTORY STUDIES

113

Volume 12

Issue 1

February 2020

\begin{tabular}{|l|l|l|l|l|l|}
\hline Ders adı & Haftalık Saat & Ücret & Ders adı & Haftalık Saat & Ücret \\
\hline Türkçe(1. sene) & 6 & 150 & Arabî & 12 & 210 \\
\hline Türkçe(2. sene) & 5 & 100 & Hesab & 11 & 210 \\
\hline Türkçe(3. sene) & 3 & 220 & Ulum-1 Diniye ve Ahlak & 18 & 280 \\
\hline Türçce(4. sene) & 3 & 100 & Resim & 6 & 110 \\
\hline Farisi & 8 & 120 & Hüsn-i hat & 7 & 140 \\
\hline Tarih & 8 & 200 & Coğrafya & 13 & 360 \\
\hline Usul defteri & 1 & 50 & Hendese & 5 & 180 \\
\hline İlmi eşya & 3 & 130 & Cebir & 2 & 120 \\
\hline Fransızca & 12 & 300 & Kitabet & 4 & 190 \\
\hline
\end{tabular}

Maarif Nezareti, 1904 yılı itibariyle, tüm idadilerin ders programlarını yeniden düzenlemiştir. $\mathrm{Bu}$ yeniliğe göre, müfredata ahlak, fikıh ve ziraat dersi eklenmiş ve derslerin saatlerinde değişiklikler yapılmıştır. ${ }^{58}$ Kudüs-i Şerif İdadi Mektebi'nin ders programında ve derslerin saatlerinde değişiklik yapılmıştır. Bu değişiklik/yeniliğe göre, ziraat dersi eklenmiş ve 18 saat olan Ulum-1 Diniye ve Ahlak dersi birbirinden ayrılarak Ulum-1 Diniye Dersi 10 saat ve Ahlak dersi ise 4 saat olarak tayin edilmiştir. Fransızca 12 saatten 9 saate; Arabî 12 saatten 10 saate; Hüsn-i Hatt 7 saatten 6 saate; Coğrafya 13 saatten 10 saate; Kitabet 4 saatten 3 saate düşürülmüş; Usul Defteri, İlmi Eşya ve Cebir dersleri de tamamen müfredattan çıkarılmıştır.

Tablo 4: 1904 Yılı İtibariyle Kudüs-İ Şerif İdadi Mektebi’nin Yeni Ders Programı; ${ }^{59}$

\begin{tabular}{|l|l|l|l|l|l|}
\hline Dersin İsmi & Haftalık Saat & Ücret & Dersin İsmi & Haftalık Saat & Ücret \\
\hline Coğrafya & 10 & 360 & 1. sınıf Türkçe & 6 & 150 \\
\hline Kitabet & 3 & 220 & 2. sınıf Türkçe & 6 & 100 \\
\hline Ahlak & 4 & 150 & 3. sınıf Türkçe & 4 & 100 \\
\hline Tarih & 8 & 200 & 4. sınıf Türkçe & 4 & 60 \\
\hline Hendese & 5 & 200 & Fransızca & 9 & 336 \\
\hline Hesab & 11 & 310 & Ulum-1 Diniye & 10 & 306 \\
\hline Ziraat Dersleri & 4 & 168 & Hüsni Hat & 6 & 110 \\
\hline Farisi & 8 & 120 & Arabi & 10 & 210 \\
\hline Resim & 5 & 120 & & & \\
\hline
\end{tabular}

Kudüs-i Şerif İdadi Mektebi Ders Programı'nda belirli ihtiyaçlardan dolayı değiş̧iklik yapılması elzem hale gelmiştir. Bu sebeple ders programına bazı derslerin eklenmesi bazı dersleri ise ders programından çıkarılması uygun görülmüştür. Kudüs-i Şerif sancağında gayr-i

${ }^{56}$ Kodaman, age, s. 126-132

${ }^{57}$ BOA, MF. MKT. 704/12

${ }^{58}$ Kodaman, age, s. 129-132

${ }^{59}$ BOA, MF. MKT, 800/70 
Müslim ile yabancıların çok olmasından dolayı İngilizce lisanı daha çok konuşulmaktaydı. Müslüman aileler ise evlatlarını İngilizce öğrensinler diye yabanc1 mekteplere göndermekteydiler. Kudüs-i Şerif Maarif Müdürlüğü, bu duruma hem bir gerekçe (İngilizce lisanının zamanın umumi lisanı olması) hem de bir çözüm (Müslim çocukların yabancı mekteplere gitmelerini engellenmesi) olarak ders programına İngilizce dersinin eklenmesini Maarif Nezareti'nden talep etmiştir. Maarif Nezareti, ders programıyla ilgili düzenlemenin 2 yıl önce yapıldığını gerekçe göstererek ders programında yeni bir değişikliğin yapılmasını (örn. İngilizce lisanın eklenmesini) uygun görmemiş ve eski programın ihtimam ile tatbik edilmesini istemiştir. $^{60}$

Kudüs-i Şerif İdadi Mektebi, 1890 yılından 1908 yılına kadar beş sınıflı olarak eğitime devam etmiştir. Ancak mektepten mezun olan öğrenciler, tahsillerine devam etmek için büyük masraflar yaparak ya Beyrut, İstanbul gibi uzak vilayetlerdeki yedi yıllık idadi mekteplerine ya da Kudüs-i Şerif sancağında bulunan yabancı mekteplere gidiyorlardı. Kudüs-i Şerif Maarif Müdürlüğü, bu durumun önüne geçebilmek için mektebin öğretim süresini, beş yıldan yedi yıla çıkarılmasını ve yatılı hale getirilmesini Maarif Nezareti'nden istemiştir. Maarif Nezareti, durumu mütalaa etmiş ve mektebin altı yıla çıkarılmasını uygun görmüş fakat yedi yıllık ve leyli olarak hizmet vermesini uygun görmemiştir. Nezaretin kararına göre, 2 Zilkade 1326 ( 26 Kasım 1908) tarihinden itibaren mektebe bir sınıf daha eklenerek mektep altı sinıflı hale getirilmiştir. Bunun üzerine altıncı sınıfın derslerini ve muallimlerin maaşını aşağıdaki şekliyle düzenlenip 21 Zilkade 1326 (15 Aralık 1908) tarihinde Maarif Nezareti'ne gönderilmiştir. Maarif Nezareti ise Kudüs-i Şerif Maarif Müdürlüğü'nün bu girişimini uygun görerek kabul etmiştir $^{61}$

Tablo 5: Kudüs-i Şerif İdadi Mektebi’nin Altıncı Sınıf Dersleri, Muallimler ve Ders Ücreti

\begin{tabular}{|l|l|l|}
\hline Dersin Adı & Muallimi & Ders Ücreti \\
\hline Kitabet-i Resmiye & Maarif Müdürü Ali Rıza Efendi & 120 \\
\hline Ahlak ve Malumat-1 Medeniye & Maarif Müdürü Ali Rıza Efendi & 40 \\
\hline Tarih-i Umumi & Maarif Müdürü Ali Rıza Efendi & 60 \\
\hline Cebir & İdadi Müdürü Kamil Efendi & 80 \\
\hline Coğrafya & İdadi Müdürü Kamil Efendi & 40 \\
\hline Hendese & İdadi Müdürü Kamil Efendi & 50 \\
\hline Hikmet & İdadi Müdürü Kamil Efendi & 80 \\
\hline Kimya & Patrik Müfettişi Simon Efendi & 80 \\
\hline Tarih-i Tabii & Patrik Müfettişi Simon Efendi & 80 \\
\hline Ulum-1 Diniye & Şeyh Hüsameddin Efendi & 40 \\
\hline Arabî & Şeyh Hüsameddin Efendi & 40 \\
\hline Fransızca & Rüşdi Efendi & 90 \\
\hline
\end{tabular}

Suriye Vilayeti Hama İdadi Mektebi ile Beyrut Vilayeti Nablus İdadi Mektebi'nde olduğu gibi Kudüs-i Şerif İdadi Mektebi'nde de bir ihtiyat sınıfının açılması istenilmiştir. Bu ihtiyat sınıfı ile talebelere daha iyi bir Türkçe lisanının öğretilmesi amaçlanmıştır. Çünkü Kudüs-i Şerif sancağındaki iptidai mekteplerden mezun olan talebelerin Türkçeyi yeterli derecede öğrenemedikleri tespit edilmiştir. İdadi mektebine başlayan bu talebelerin dersleri anlamada

\footnotetext{
${ }^{60}$ BOA, MF. MKT, 942/22

${ }^{61}$ BOA, MF. MKT. 1104/66
} 
sıkıntı yaşadığı ve haliyle başarı seviyeleri düşmeye başladığı gözlemlenmiştir. Kudüs-i Şerif Maarif Müdürlügü, bu durumun önüne geçilebilmek için talebelere Türkçe mükâleme (karşılıklı konuşma), tercüme ve imla gibi konuların öğretilmesini ve bunun içinde yeterli bir maaş ile uygun bir muallimin tayin edilmesini 1 Safer 1321 (29 Nisan 1903) tarihli yazı ile Maarif Nezareti'nden istemiştir. Maarif Nezareti, talep edilen ihtiyat sınıfının açılmasını uygun görmüştür. Ancak aylık 250 kuruştan muallim tayin olunmasına ve muallim maaşının Kudüs-i Şerif Mahalli Bütçesi'nden veya Kudüs-i Şerif Evkaf Gelirleri’nden karşılanmasına karar vermiştir. ${ }^{62}$

\section{Mektebin Materyal İhtiyacının Temini}

Osmanlı Devleti'ndeki idadi mekteplerinde eğitim ve öğretim malzemesi olarak ders kitapları, tahta, tebeşir, düzlem küre haritası, harita, atlas kullanılmış ${ }^{63}$ ve bu malzemeler, Meclis-i Kebir-i Maarif'inin bir alt birimi olan Daire-i İdare'ye bağlı Maarif Kütüphanesi’nden temin edilerek mekteplere gönderilmiştir. ${ }^{64}$

Kudüs-i Şerif İdadi Mektebi'nde Coğrafya dersinde kullanılan Osmanlı Avrupa ve Osmanlı Asya haritası kullanılamaz hale gelmiştir. Coğrafya dersinin daha etkili bir şekilde anlatılması için haritalar ve dünya küresi Maarif Nezareti’nden talep edilmiştir. Maarif Nezareti, belirtilen haritalar ile dünya küresinin Maarif Kütüphanesi'nden temin edilerek 800 kuruş karşıllı̆ğında göndereceğini Kudüs-i Şerif Maarif Müdürlüğü’ne bildirmiştir. ${ }^{65}$

Aynı şekilde mektepte kullanılan Osmanlı Devleti'nin hüküm sürdüğü eyalet, sancak ve kazaları gösteren haritalar zamanla kullanılmaz hale gelmiştir. Kudüs-i Şerif Maarif

Volume 12

Issue 1

February 2020

Müdürlüğü, yeni haritaların gönderilmesi için Maarif Nezareti’nden talep etmiştir. Maarif Nezareti, yeni haritaların tamamının Maarif Kütüphanesi'nde bulunmadığını ancak Avrupa ve Afrika haritası ikişer adet olarak meccanen gönderileceğini Kudüs-i Şerif Maarif Müdürlüğü’ne bildirmiştir. ${ }^{66}$

1894-1895 eğitim-öğretim döneminde mezun olacak talebeye (umumi imtihan sonucunda) usulen şahadetname verilecekti. Ancak mektepte şahadetname kalmadığ 1 için 30 adet şahadetname Maarif Nezareti'nden istenilmiştir. Maarif Nezareti, gerekli şahadetnamelerin depoda kalmadığı ancak basımı yapılır yapılmaz gönderileceği Kudüs-i Şerif Maarif Müdürlüğü'ne bildirmiş ${ }^{67}$ ve şahadetnameler yaklaşık altı ay sonra mektebe gönderilmiştir. ${ }^{68}$

\section{Mektepte Yapılan Tamiratlar}

Kudüs-i Şerif İdadi Mektebi 1890 yılından itibaren eğitim-öğretime yılına resmi olarak başlamıştır. Mektep zamanla tahrip olmuştur. $\mathrm{Bu}$ sebeple mektebin binası, çevresi ve içerisindeki tefrişatı tamire muhtaç hale gelmiştir.

${ }^{62}$ BOA, MF. MKT. 713/45

${ }^{63}$ Demirel, age, s. 168

${ }^{64}$ Bahri Ata, "Osmanlı İmparatorluğu Döneminde Bir Ders Araç ve Gereçleri Lojistik Merkezi: Maarif Kütüphanesi

(1872-1895)", Tarihin Peşinde Uluslararası Tarih Sosyal Araștırmaları Dergisi, Sayı: I, 2009, s. 29-31

${ }^{65}$ BOA, MF. MKT. 162/103

${ }^{66}$ BOA, MF. MKT. 987/61

${ }^{67}$ BOA, MF. MKT. 278/26

${ }^{68}$ BOA, MF. MKT. 316/70

\section{History Studies}


Bu tamirlerden birkaçı, mektep abdesthanesine bitişik olan duvarın yıkılmış olmasıdır. Buna binaen duvarın tamiri için gerekli paranın 2500 kuruş olduğu tespit edilmiş ve bunun için keşif defteri hazırlanılarak 16 safer 1313 (8 ağustos 1895) tarihinde Maarif Nezareti'ne gönderilmiştir. Maarif Nezareti ise duvarın tamiratı için gerekli olan 2500 kuruşun 1896 Yllı Kudüs-i Şerif Maarif Müdürlüğ̈̈'nün İnşaat Tertibatı'ndan karşılanmasına izin vermiştir. ${ }^{69}$

Mektebin muslukları, tuvalet kapıları ve sıralarının tamir edilmesi elzem hale gelmiştir. Bundan dolayı, tamiratın bedelinin 4370 kuruş olarak keşif defteri hazırlanılarak 4 Rebiyülevvel 1320 (11 Haziran 1902) tarihinde Maarif Nezareti'ne gönderilmiştir. Maarif Nezareti ise keşif defterini incelemiş ve tamirat için 4370 kuruşun fazla olduğunu belirtmiştir. Bu miktar yerine 3000 kuruşun yeterli olacağının kararını vermiş ve bunun da 1902 Yllı Kudüsi Şerif Maarif Müdürlüğ̈̈'nün İnşaat Tertibatı'ndan karşılanmasına karar vermiştir. ${ }^{70}$

Mektebin on sekiz tane yeni sıraya ihtiyacının yanında mektepteki elli üç sıranın da tamir edilmesi gerektiği görülmüştür. Bunun için de 1950 kuruşa ihtiyaç olduğu tespit edilmiş ve keşif defteri hazırlanılarak Maarif Nezareti'ne bildirilmiştir. Maarif Nezareti ise keşif defterini incelemiş, yeni sıra yapımı ve eski sıraların tamiri için 1950 kuruşun 1908 Yll Kudüs-i Şerif Maarif Müdürlüğ̈̈'nün İnşaat Tertibatı'ndan karşılanmasına karar vermiştir. ${ }^{71}$

Mektebin doğu tarafındaki duvarının taşları dökülmeye başlamış ve duvarın tamiri için 3650 kuruşa ihtiyaç olduğuna dair keşif defteri hazırlanılarak Maarif Nezareti'ne bildirmiştir. Maarif Nezareti, keşif defterini incelemiş, tamir için gerekli olan 3650 kuruşun 1908 Yllı Kudüs-i Şerif Maarif Müdürlü̈̆̈̈'nün İnşaat Tertibatı'ndan karşılanmasına karar vermiştir. ${ }^{72}$

\section{Mektebin Sultaniye Dönüştürülmesi}

II. Meşrutiyet döneminde Osmanlı'daki idadilerin eğitim kalitesinde düşüş yaşanmıştır. Bunun delili olarak ise idadiler, hem Osmanlı'da bulunan yabancı mekteplerle rekabet edemez hale gelmiş hem de Avrupa'daki liselerin çok gerisinde kaldığı tespit edilmiştir. Böylelikle idadi mekteplerinin yapısında değişikliğe gidilmiştir. Bu değişiklikle, Müslüman talebelerin yabancı mekteplere müracaat etme mecburiyetlerini ortadan kaldırılmak amaçlanmıştır. Böylelikle ilk icraat olarak, 14 Ekim 1910 tarihinde, İstanbul, Edirne, Adana, Aydın (İzmir), Üsküb, Bursa, Beyrut, Haleb, Selanik, Trabzon, Mamuretülaziz ve Kastamonu olmak üzere on iki idadi mektebi sultaniye dönüştürülmüştür. 1913-1914 yıllarında da çeşitli idadi mektepleri sultaniye çevrilmiştir. Osmanlı eğitim sisteminin ortaöğretim kurumlarını oluşturan sultanilerin sayısı otuz altıya ulaşmıştır. ${ }^{73}$ Sultani'ye çevrilen idadilerden biri de Kudüs-i Şerif İdadi Mektebi'dir.

Kudüs-i Şerif Mutasarrıfı Macid Şevket Efendi, 1913 yılında Kudüs-i Şerif sancağını teftiş etmiş ve teftiş sonucunda mülki, nafia ve maarifle alakalı notlar tutmuştur. Bu notlar içerisinde maarifle ilgili olan görüşünü Maarif Nezareti'ne şu şekilde bildirmiş̧ir: Kudüs-i Şerif sancağı

\footnotetext{
${ }^{69}$ BOA, MF. MKT. 320/61

${ }^{70}$ BOA, MF. MKT. 668/52

${ }^{71}$ BOA, MF. MKT. 1038/55

72 BOA, MF. MKT. $1104 / 32$

73 Fatih Demirel, "II. Meşrutiyetten Sonra Osmanlı'da Orta Öğretim: Sultaniler", Tarih İncelemeleri Dergisi Cilt XXVII, Say1 2 Aralık 2012, s. 342-344
} 
merkezinde yabancı mektepler, özel mektepler, resmi olarak ise bir rüştiye ve altı yıllık nehari (gündüz) idadi mektebi bulunmaktadır. İdadi mektebinden mezun olan talebeler, yüksek tahsillerini yapmak için ya yabancı veya özel mekteplere ya da birçok masraflarla Beyrut, İstanbul gibi idadilere gitmek zorunda kalıyorlar. Macid Şevket Efendi, Kudüs-i Şerif sancağı merkezinde yedi yıllık leyli (yatılı) bir idadi mektebi ya da sultani mektebinin açılmasının gerekli olduğunu ifade etmiştir. Ayrıca Kudüs-i Şerif sancağı gelirlerinin yetersiz olduğunu görmüş, bu yüzden gerekli masrafların Maarif Nezareti tarafından karşılanmasının daha muvafık olacağını belirtmiştir. Macid Şevket Efendi'nin beyanatları Maarif Nezareti'nde görüşülmüş ve idadi mektebinin, leyli (yatıl1) sultani mektebine çevrilmesine/dönüştürülmesine karar verilmiştir. Ancak Maarif Nezareti, mevcut idadi mektep binasının sultani mektebi için müsait olup olmadığına; binada yeterli sayıda derslik ile yüz kişilik yatakhane, mutfak, çamaşırhane bulunup bulunmadığına; binada tadilat ve yeni eklemelerin yapılıp yapılmayacağına dair planların gönderilmesini istemiştir. Ayrıca masrafların imkân dâhilinde bütçeden karşılanacağını ${ }^{74} 15$ Şaban 1331 (20 Temmuz 1913) tarihli yazı ile bildirmiştir. Macid Şevket Efendi, istenen planları Kudüs-i Şerif Nafia Başmühendisliği'ne hazırlatmış ve gerekli tadilata başlamak için Maarif Nezareti'nden izin istemiştir. Nezaret, gerekli incelemeleri yaptıktan sonra tadilat için 27 Ramazan 1331 (30 Ağustos 1913) tarihinde vermiş̧tir. Macid Şevket Efendi, tadilatın yaklaşık bir ay süreceğini, dolayısıyla H.1331 (M.1913) yılının Zilkade (Ekim) ayı başında mektebin eğitim ve öğretime hazır hale geleceğini 20 Şevval 1331(22 Eylül 1331) tarihinde Nezarete bildirmiştir. İdadi mektebindeki tadilat öngörülen tarihte tamamlanarak sultani mektebine dönüştürülmüsstür. Kudüs-i Şerif sancağındaki idadi mektebi 18 Zilkade 1331 (18 Ekim 1913) tarihinden itibaren sultani mektebi olarak hizmet vermeye başlamış ve bu durum yerli halk tarafından sevinçle karşılanmıştır. ${ }^{75}$

\section{Sonuç}

Osmanlı Devleti, uzun bir süre eğitim sistemini geleneksel modelle icra etmiştir. Modernleşme hareketiyle birlikte modern eğitim sistemine geçmiş ve bu sisteme ağırlık vermiştir. Modern eğitim sisteminin temel özelliği, merkezi yönetime dayanması ve iptidai, rüştiye, idadi, sultani ve meslek okulları şeklinde tasnif edilmesidir. Osmanlı Devleti, bu modeli ilk olarak İstanbul'da daha sonra ise taşra teşkilatında uygulamaya başlamıştır. Bu uygulamadan nasibini Kudüs-i Şerif sancağı da (idadi mektebi açılarak) almıştır.

Modern eğitim sistemi, 1869 Nizamnamesi'ne göre işlevini icra etmiştir. İdadi mektebi de modern eğitim sistemi içinde yer aldığı için Nizamname'ye tabi tutulmuştur. Nizamname'nin en büyük özelliği, merkezi ve hiyerarşik bir yapı ortaya koymasıdır. Bu sebeple idadi mektebiyle ilgili herhangi bir durum hâsıl olduğunda İdadi Mektep Müdürü, bu durumu Maarif Müdürlüğ̈̈’ne, Maarif Müdürlügü ise Maarif Nezareti’ne keşif defterleriyle intikal ettirirdi.

1869 yılına kadar Osmanlı Devleti'nde rüştiye mekteplerinin sayısı artmış, İstanbul'da ise çok sayıda meslek okulu ve yüksekokul açılmıştır. Ancak vilayetlerde rüştiye üstünde ve İstanbul'da yüksekokullara talebe yetiştirecek -rüştiye dışında- bir okul olmadığından idadi

\footnotetext{
74 İdadinin sultani mektebine çevrilme masrafları için gerekli olan 1000 liranın öncelikle Kudüs-i Şerif sancağı ahalisinden toplanacağına dair sancak mutasarrıfı tarafından taahhüt alınmıştır. ( BOA, MF. MKT. 1188/20)

${ }^{75}$ BOA, MF. MKT. 1188/20
} 
okulların açılması elzem hale gelmiştir. Bunun için 1869 Maarif Nizamnamesi ile idadi mektepleri yeniden düzenlenerek Osmanlı eğitim sisteminde yerini almıştır. 1869 Maarif Nizamnamesi'nde hemen açılmaları öngörülen idadiler, maddi imkânsılılılar ve öğretmen yetersizliğinden dolayı 1874 yılına kadar açılamamıştır. Sadrazam Said Paşa'nın girişimleri ile sağlanan mali kaynak sayesinde 1885 yılından itibaren vilayetler ve sancak merkezlerinde idadi mektepleri açılmaya başlamıştır.

Osmanlı Devleti'nin diğer sancak merkezlerinde olduğu gibi Kudüs-i Şerif Sancağı merkezinde de beş sınıflı ve nehari (gündüzlü) idadi mektebinin yapılmasına 1885 yılında karar verilmiştir. Kudüs-i Şerif Sancağı merkezinde bulunan Memuniye Medresesi arsası üzerine idadi mektebi yapılmaya başlanmış ve 1890 yılında mektebin açılışı yapılmıştır. Kudüs-i Şerif İdadi Mektebi'nin açı1ışı yapılmasının ardından mektebe müdür, muallim, mubassır ve hademe gibi görevliler Kudüs-i Şerif halkından olduğu gibi İstanbul'dan da tayin edilmiştir. İdadi mektebindeki görevliler tayin, hastalık ve ölüm gibi nedenlerle zaman içerisinde değişmiştir.

Mektebin idaresinde en üst amir müdürdü. Müdürün asli vazifesi, mektebin işleyişini disiplin içerisinde sağlamaktı. Muallimlerin önemi ise yadsınamaz. Mektebe asıl nitelik kazandıran muallimlerin donanımlarıydı. Bu sebeple nitelikli muallimler ödüllendirilmekteydi. Her eğitim ve öğretim yılı başında talebe sayısı cetvele işlenmiş ve bu cetveller Maarif Nezareti'ne gönderilmiştir. Maarif Nezareti (cetvellere göre), eğer talebe sayısında düşüş yaşanmışsa ne gibi tedbirlerin alınması gerektiğini bildirmiştir.

Kudüs-i Şerif İdadi Mektebi, değişen koşulları ve çevre dinamiklerini göz önünde bulundurarak Türkçe-İngilizce lisanın talim edilmesinde karar kılmıştır. Böylelikle diğer vilayetlere giden talebelere iyi bir alternatif oluşturmaya çalışmışır. Öte yandan Maarif Müdürlügü̈'nden nitelikli muallimler istemiştir. Çünkü nitelikli muallimlerin varlığı talebeyi mektebe sevk ettiği bilinmekteydi. Bu realite ve idadi mektebinin işleyişi göz önünde tutularak günümüz ile ilişkisi kurulabilir. Örneğin Eğitim Bakanlığı yeni bir okulun açılmasında değişen koşulları ve çevre ihtiyacını dikkate alarak ve aynı zamanda nitelikli hocaları bu yeni açılan okullara tayin ederek hem o bölgedeki eğitim seviyesini yükseltecek hem de bölgenin ülke genelinde ciddi bir başarı yakalamasına öncü olacaktır.

\section{Kaynakça}

\section{Arşiv Kaynakları}

BOA, Dâhiliye Nezareti İrade Dâhiliye Evrakı (İ.DH.) , 1054/82713

BOA (Devlet Arşivleri Başkanlığ 1 Osmanlı Arşivi) Maarif Nezareti Mektubi Kalemi Evrakı, (MF. MKT.): 143/24; 101/48; 102/43; 102/65; 115/68; 120/94; 320/61; 668/52; 1038/55; $1104 / 32 ; 132 / 89 ; 163 / 1 ; 479 / 4 ; 898 / 50 ; 932 / 59 ; 958 / 73 ; 1013 / 3 ; 1005 / 1 ; 245 / 27 ; 800 / 70$; $136 / 45 ; 149 / 127 ; 190 / 112 ; 657 / 40 ; 812 / 33 ; 919 / 20 ; 922 / 17 ; 173 / 99 ; 704 / 12 ; 942 / 22$; $1104 / 66 ; 713 / 45 ; 162 / 103 ; 987 / 61 ; 278 / 26 ; 316 / 70 ; 1188 / 20$

H. 1316, H. 1317, H. 1318, H. 1319, H. 1321 Maarif Nezâreti Salnameleri 


\section{II. İnceleme ve Araştırmalar}

ATA, Bahri, "Osmanlı İmparatorluğu Döneminde Bir Ders Araç ve Gereçleri Lojistik Merkezi: Maarif Kütüphanesi (1872-1895)', Tarihin Peşinde Uluslararası Tarih Sosyal Araştırmaları Dergisi, Sayı: I, 2009, ss.27-36.

AVCI, Casim, "Fethedilişinden Haçlı İstilâsına Kadar: Kudüs", DİA, C. 26, Ankara 2002, ss. 327-329

BATUK, Cengiz, Rabia Mert, "Çatışan Kutsalların Ortasındaki Şehir: Kudüs”, Din Bilimleri Akademik Araştırma Dergisi, Cilt 17, Sayı 2, 2017, ss.129-149

DEMİREL, Fatih, “II. Meşrutiyetten Sonra Osmanlı'da Orta Öğretim: Sultaniler”, Tarih Incelemeleri Dergisi Cilt/Volume XXVII, Say1 2 Aralık 2012, ss.339-358.

DEMİREL, Fatih, “Kuruluşundan Günümüze Vefa Lisesi”, Prof. Dr. Yahya Akyüz'e Armağan Türk Ĕ̌itim Tarihi Araştırmaları, Eğitim ve Kültür Yazıları, Pegem Akademi Yayınları, Ankara 2010, ss.608-618.

DEMİREL, Fatih, “Osmanlı Eğitim Sisteminin Modernleşmesi Sürecinde Hiyerarşi”, Uludăg Üniversitesi Ĕgitim Fakültesi Dergisi, 25 (2), 2012, ss.507-530.

DEMİREL, Fatih, Mekteb-i İdâdî, (Atatürk Üniversitesi, Sosyal Bilimler Enstitüsü, Yayınlanmamış Doktora Tezi), Erzurum 2010.

Volume 12

DEVELLİĞGLU, Ferit, Osmanlıca-Türkçe Ansiklopedik Lûgat, Aydın Kitabevi Yay. Ankara, Bask1:30, İ Maddesi. 2013.

el-ASELÎ, Kâmil Cemîl, “Osmanlı Dönemi ve Sonrası: Kudüs”, DİA, C. 26, Ankara 2002, ss.334-338

KODAMAN, Bayram, Abdülhamid Devri Eğitim Sistemi, Türk Tarih Kurumu Yay. Ankara, 1999.

ÖZTÜRK, Cemil, "İdâdî”, DİA, C.21, İstanbul, 2000.

TEKIN, Kemal Hakan, "Osmanlı Devletinde Gelenekten Yeniliğe Geçişin Anlamlı Bir Sembolü: Mecidi Nişanları" The Journal of Academic Social Science Studies, Number: 28, Autumn II, 2014, ss. 393-411.

TOMAR, Cengiz, Memlükler Dönemi: Kudüs”, DIA, C. 26, Ankara 2002, ss.332-334

UNAT, Faik Reşit, Türk Eğitim Sisteminin Gelişmesine Tarihi Bir Bakış, Milli Eğitim Bakanlığı Yayınevi, Ankara, 1964.

YILDIZ, Hatip, "Üsküdar (Paşakapısı) Mülki İdadi Mektebi (1893-1923)”, Uluslararası Üsküdar Sempozyumu VIII, 21-23 Kasım 2014 C.I, İstanbul 2015, ss.419-449. 


\section{Ekler}

Ek 1: Kudüs İdadi Mektebi Hüsn-i Hat Muallimi Said Efendi’nin Yazı Örneği

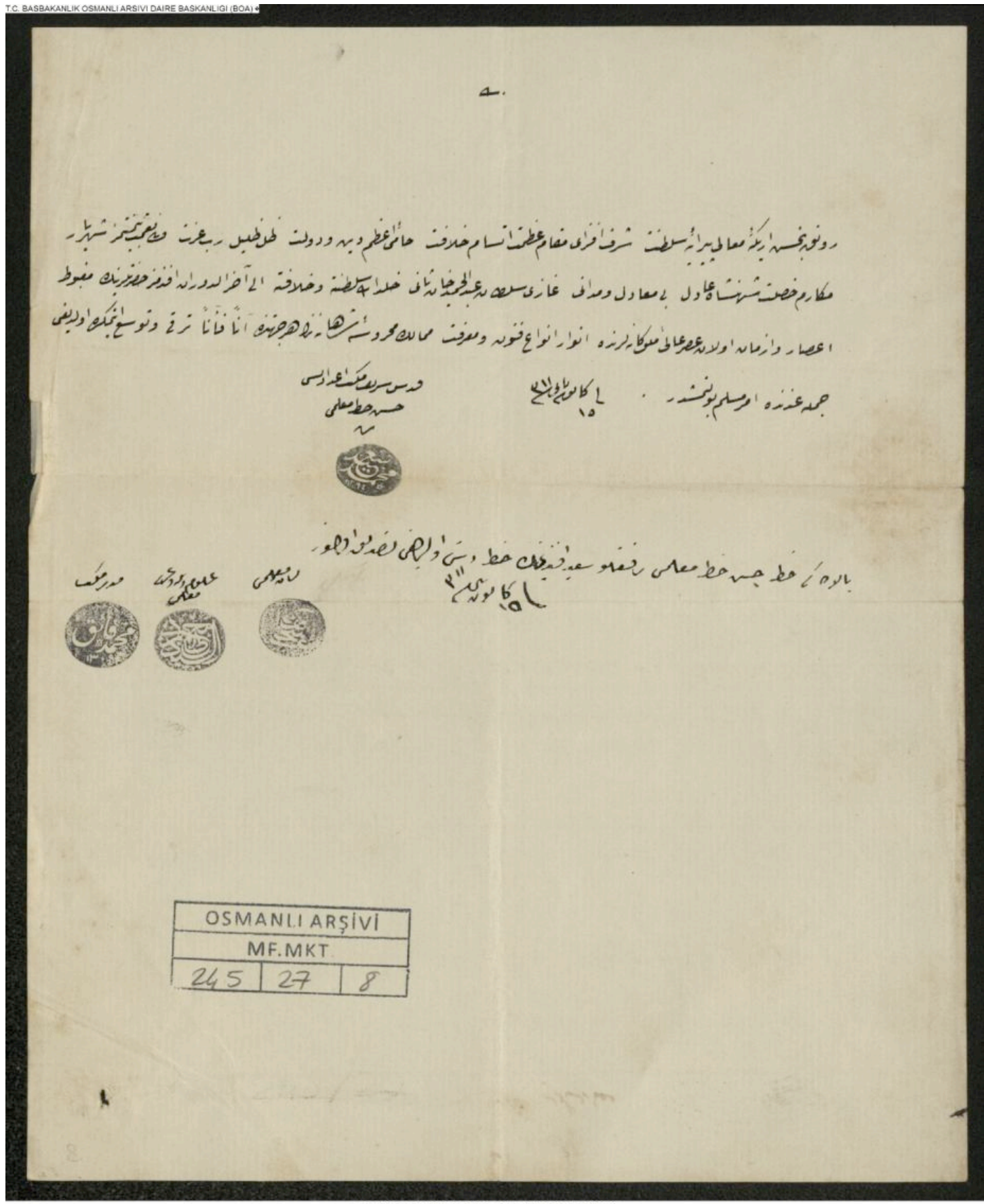

MF.MKT.00245.00027.008 
Ek 2: Kudüs-i Şerif İdadi Mektebi’nin Tarih Dersi Muallimliğine Tayin Olunan Mekteb-i İbtidai Muallimi Rüşdi Efendinin İmtihan Evrakı

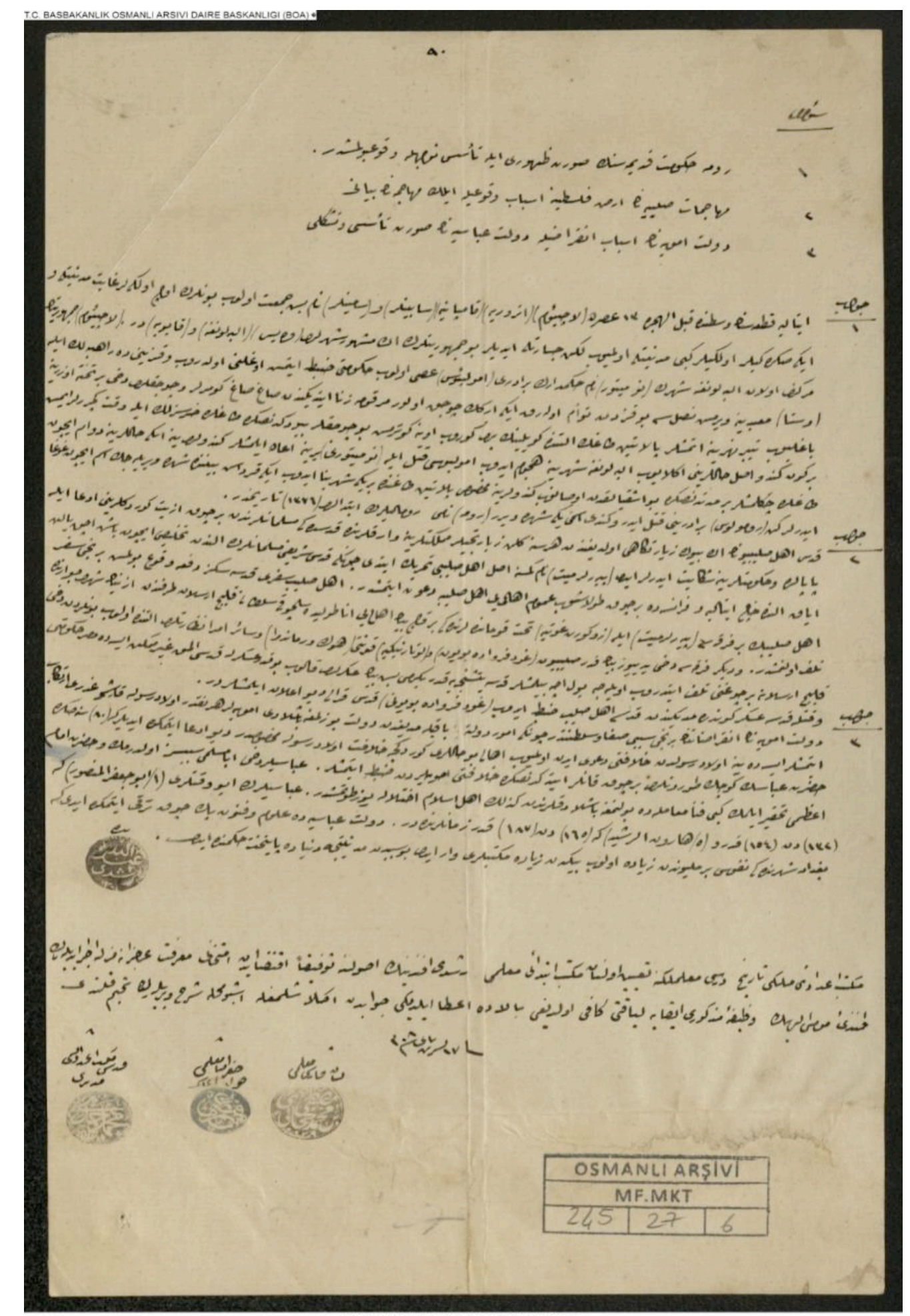

MF.MKT.00245.00027.006 
Kudüs-i Şerif İdadi Mektebi (1890-1913)

Ek 3. Kudüs-i Şerif İdadi Mektebi’nin Leyli Sultaniye Tahvili İçin Gerekli Tadilatı Gösteren Plan

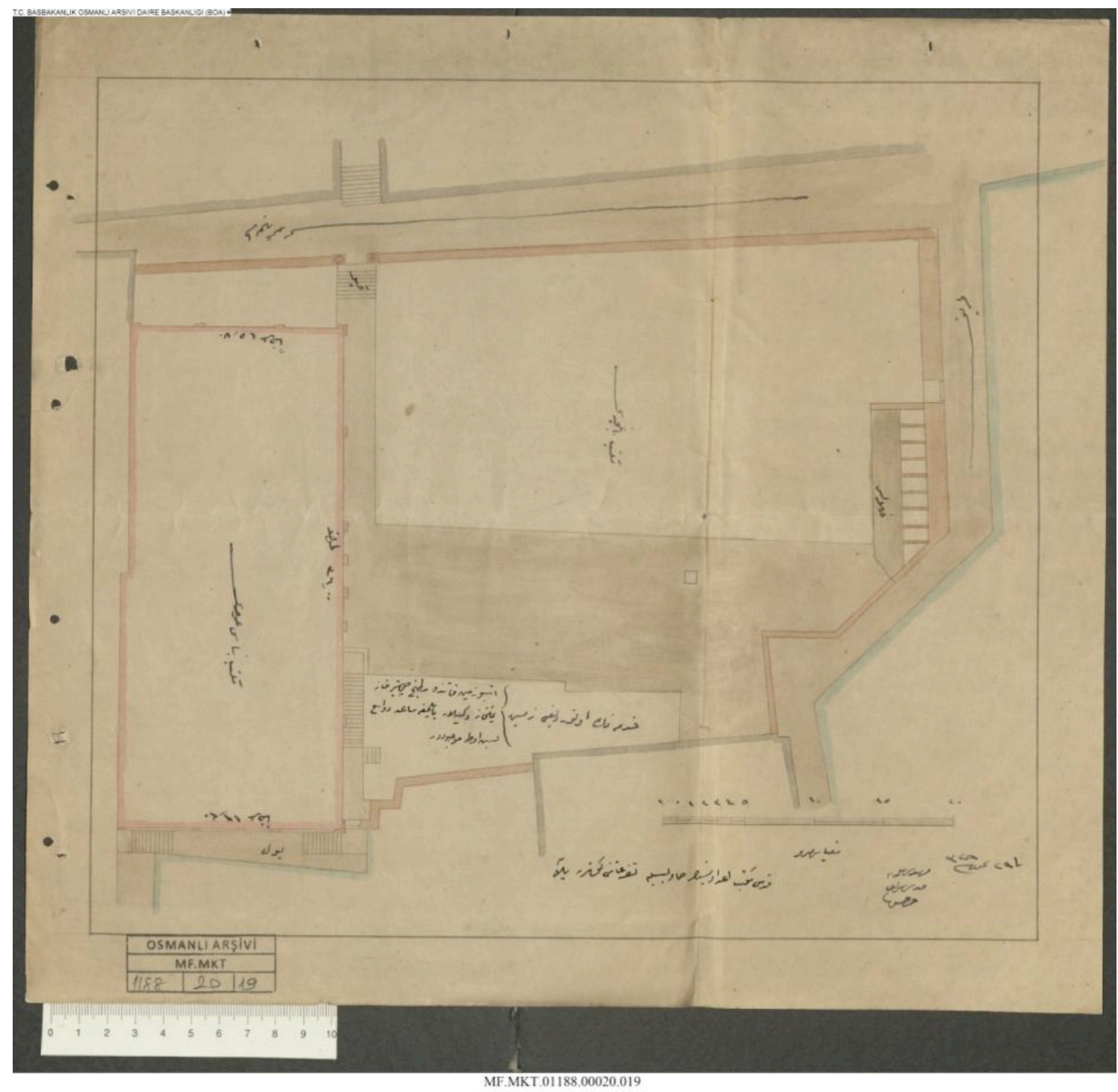

Volume 12

Issue 1

February

2020 
Abdullah Cengiz

Ek 4: Leyli Sultaniye Tahvil Edilecek Olan Kudüs-i Şerif İdadi Mektep Binasının Alt Kat Planı

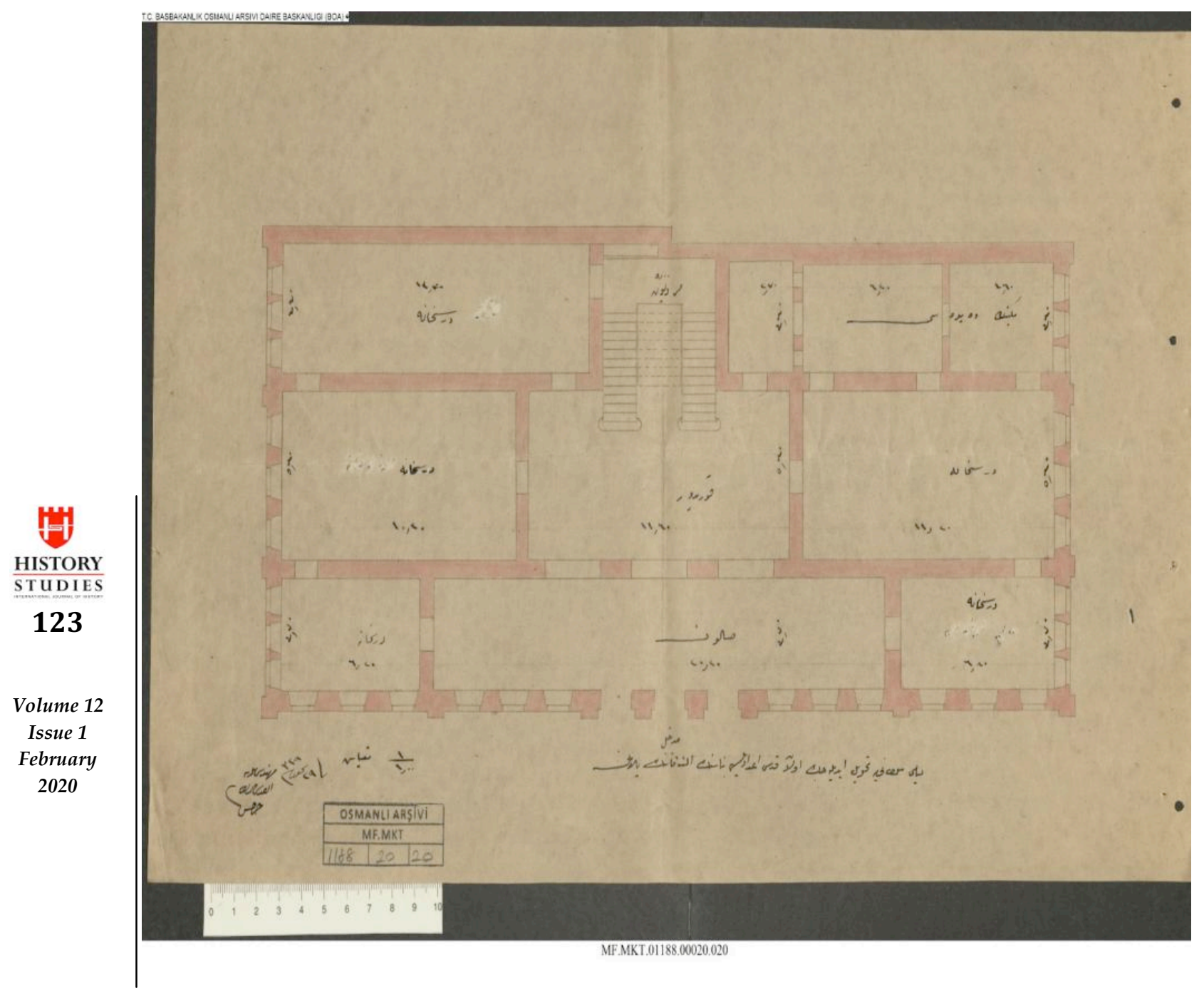




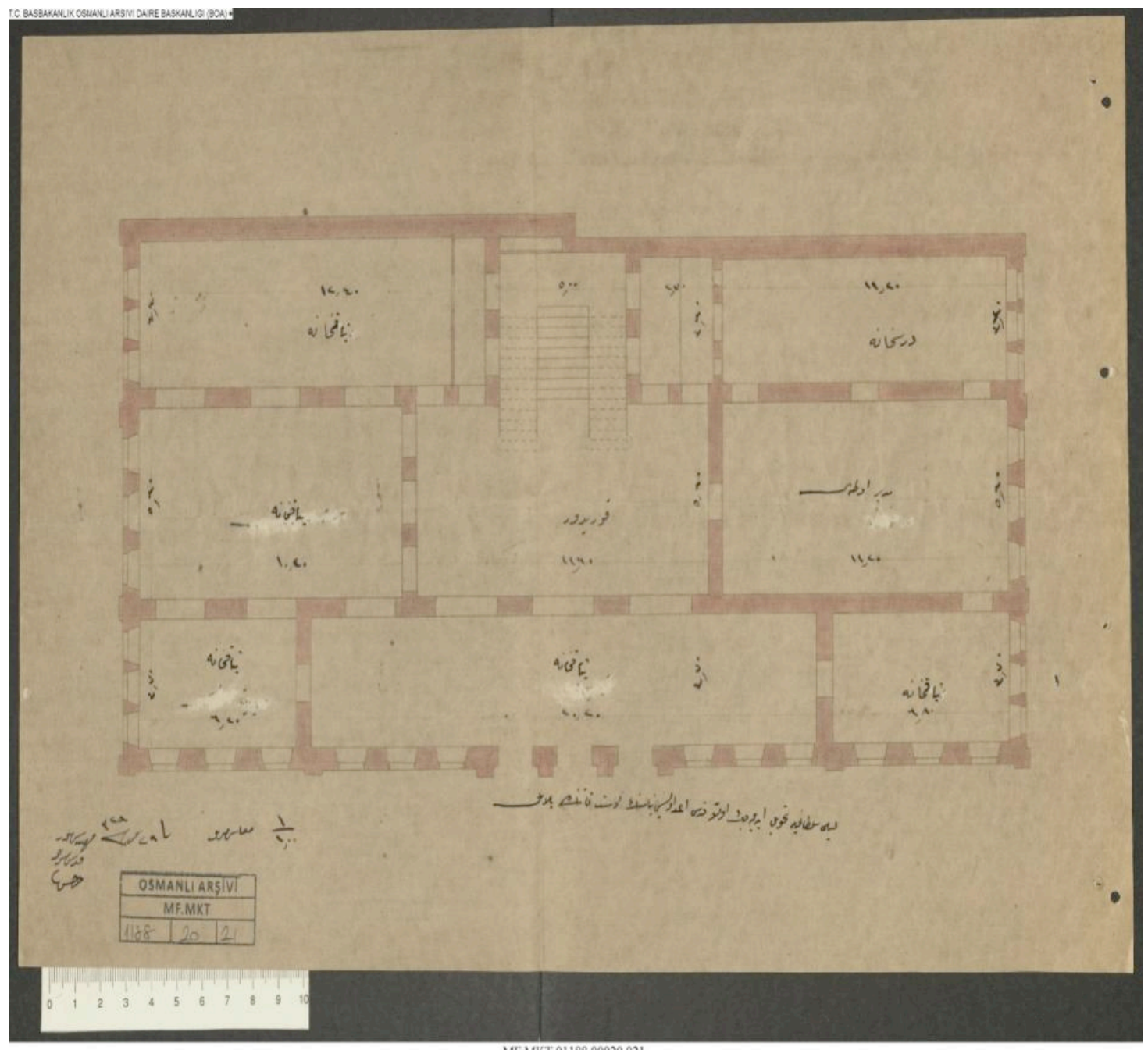

